\title{
Mothers' reports of infant crying and soothing in a multicultural population
}

\author{
M F van der Wal, D C van den Boom, H Pauw-Plomp, G A de Jonge
}

\begin{abstract}
Objectives-To investigate the prevalence of infant crying and maternal soothing techniques in relation to ethnic origin and other sociodemographic variables.

Design-A questionnaire survey among mothers of 2-3 month old infants registered at six child health clinics in Amsterdam, the Netherlands.

Subjects-A questionnaire on sociodemographic characteristics and crying behaviour was completed for 1826 of 2180 $(84 \%)$ infants invited with their parents to visit the child health clinics. A questionnaire on soothing techniques was also filled out at home for $1142(63 \%)$ of these infants.

Results-Overall prevalences of "crying for three or more hours/24 hour day", "crying a lot", and "difficult to comfort" were $7.6 \%, 14.0 \%$, and $10.3 \%$, respectively. Problematic infant crying was reported by $20.3 \%$ of the mothers. Of these infants, only $14 \%$ met all three inclusion criteria. Problematic crying occurred less frequently among girls, second and later born children, Surinamese infants, and breast fed infants. Many mothers used soothing techniques that could affect their infant's health negatively. Shaking, slapping, and putting the baby to sleep in a prone position were more common among non-Dutch (especially Turkish) mothers than among Dutch mothers. Poorly educated mothers slapped their baby more often than highly educated mothers.

Conclusions-Mothers' reports of infant crying and soothing varied sociodemographically. Much harm may be prevented by counselling parents (especially immigrants) on how and how not to respond to infant crying. Health education should start before the child's birth, because certain soothing techniques could be fatal, even when practised for the first time.

(Arch Dis Child 1998;79:312-317)
\end{abstract}

Keywords: infant crying; soothing; ethnic origin

Municipal Health Service Amsterdam, Department of Child Health Care

H Pauw-Plomp

Prins Bernhardlaan 50, 2341 KL Oegstgeest, Netherlands

G A de Jonge

Correspondence to: Dr van der Wal.

Accepted 10 March 1998 ing is unknown. In other Western countries it varies from $3 \%$ to $30 \%$ in the first four months of life, depending on the sampling design and the definition of excessive crying. ${ }^{1-10}$ A frequently used definition is crying for three or more hours/24 hour day. ${ }^{256}$ According to the most subjective definition, an infant cries excessively when the parents state that it cries a lot. ${ }^{11}$ Other definitions have accorded less importance to the actual amount of crying; other factors are stressed, such as unresponsiveness to soothing. ${ }^{12}$ In most studies, only one definition for excessive crying is used. To our knowledge, no study to date includes these three definitions of problematic infant crying.

Cultural factors might influence the amount of infant crying-for example, differences in patterns of feeding and care. ${ }^{13}{ }^{14}$ Some studies report effects of care giving styles on the amount of crying. ${ }^{15-18}$ From this perspective, excessive crying can be regarded as a response to the (Western) care giving style. Cultural factors influence maternal soothing techniques too. ${ }^{1920}$

Information about cultural differences concerning the amount of crying and soothing techniques is based mainly on cross cultural comparisons. Little is known about differences between ethnic groups living in a multicultural society. We examined the prevalence of reported infant crying (using three different definitions) as well as reported maternal soothing techniques in relation to ethnic origin and other sociodemographic variables.

Subjects and methods

We conducted a survey during the routine sociomedical examinations of infants aged 2-3 months in six out of 21 child health clinics belonging to the Municipal Health Service of Amsterdam. The combined population of these six child health clinics is representative of all infants in Amsterdam with respect to sex, ethnic origin, and maternal educational level.

\section{DATA COLLECTION}

The study was conducted between January 1995 and December 1996. During this period, 2180 infants aged 2-3 months and their mothers were invited to visit the child health clinics at the addresses registered in the municipal population register. All residents of the city of Amsterdam are registered in the municipal population register. The nurses and physicians from the collaborating child health clinics filled out a questionnaire on sociodemographic characteristics and the child's crying history. Interpreters were used if the mother did not speak Dutch: for non-Dutch speaking Turkish and Moroccan mothers a female interpreter was present during the sociomedical examination; for other ethnic groups the health centres 
Table 1 Study population $(n=1826)$ according to sociodemographic factors and crying behaviour

\begin{tabular}{|c|c|c|}
\hline & $n$ & $\%$ \\
\hline \multicolumn{3}{|l|}{ Sociodemographic characteristics } \\
\hline \multicolumn{3}{|l|}{ Sex } \\
\hline Female & 861 & 47.2 \\
\hline Male & 965 & 52.8 \\
\hline \multicolumn{3}{|l|}{ Parity } \\
\hline Second and later born children & 888 & 48.6 \\
\hline First born children & 938 & 51.4 \\
\hline \multicolumn{3}{|l|}{ Ethnic origin } \\
\hline Dutch & 989 & 54.2 \\
\hline Surinamese & 246 & 13.5 \\
\hline Turkish & 100 & 5.5 \\
\hline Moroccan & 190 & 10.4 \\
\hline Other & 301 & 16.5 \\
\hline \multicolumn{3}{|l|}{ Education of the mother } \\
\hline High & 1009 & 55.3 \\
\hline Poor & 817 & 44.7 \\
\hline \multicolumn{3}{|l|}{ Type of feeding } \\
\hline Breast & 657 & 36.0 \\
\hline Formula & 832 & 45.6 \\
\hline Mixed & 337 & 18.5 \\
\hline \multicolumn{3}{|l|}{ Crying behaviour } \\
\hline \multicolumn{3}{|c|}{ Crying for three or more hours per 24 hour day } \\
\hline No & 1687 & 92.4 \\
\hline Yes & 139 & 7.6 \\
\hline \multicolumn{3}{|l|}{ Crying a lot } \\
\hline No & 1571 & 86.0 \\
\hline Yes & 255 & 14.0 \\
\hline \multicolumn{3}{|l|}{ Difficult to comfort } \\
\hline No & 1638 & 89.7 \\
\hline Yes & 188 & 10.3 \\
\hline
\end{tabular}

called in the help of an interpreter by telephone. All Surinamese residents speak Dutch. A second questionnaire on soothing techniques was given to the mother to be filled out at home and returned to the Municipal Health Service by prepaid mail. The questionnaire was available in Dutch, Dutch-Turkish, Dutch-Moroccan or Dutch-English, as appropriate. Although neither questionnaire included the name of the subject, they were linked using a unique serial number.

OUESTIONNAIRE

Data on infant crying were collected by means of a retrospective questionnaire. This method is fast, convenient, and suitable for large scale use in measuring mother' perceptions of and responses to infant crying. ${ }^{4}$ Other methods often used to obtain information on the amount of infant crying are audiotape record- ings and prospective diaries. Audiotape recordings are too expensive for use in large samples. Prospective diaries are unlikely to be completed in low socioeconomic groups and ethnic minorities. ${ }^{21}$ Furthermore, the amount of crying reported by Western mothers in diaries and questionnaires is comparable. ${ }^{42}$

Mothers were asked to report the total amount of crying in hours/24 hour day, on average, in the previous week. Excessive crying was defined as crying for three or more hours/24 hour day. Mothers were also asked whether their baby cries a lot, and whether their baby is easy or difficult to soothe. The interpretation of infant crying was left to the mothers themselves. Sociodemographic data included age and sex of the child, birth order, ethnic origin, educational level of the mother, and type of infant feeding. Ethnic origin was defined according to the mother's country of origin: the Netherlands, Surinam (former Dutch colony in South America), Morocco, Turkey, and other countries. The mother's educational level was defined as poor (primary school or lower secondary school) or high (higher secondary school or post-secondary education), based on the highest educational level achieved.

The questionnaire on soothing techniques listed various responses to crying. The sensitive questions were hidden within a set of other, more neutral questions. Mothers were asked whether they had ever used each of the soothing techniques: for example, "Have you ever slapped your baby to make it stop crying?".

\section{STATISTICAL ANALYSES}

We used the statistical package SPSS/PC to analyse the data. ${ }^{23}$ Chi-squared tests were used to examine univariate associations between crying behaviours and various sociodemographic variables. Next, logistic regression was used to assess the relative importance of each of the sociodemographic variables on the prevalence of problematic infant crying. Logistic regression was also used to determine the relative effect of sociodemographic variables

Table 2 Percentages, multivariate odds ratios (OR), and 95\% confidence intervals (CI) for crying for three or more hours per 24 hour day, crying a lot, and inconsolable crying according to sociodemographic factors

\begin{tabular}{|c|c|c|c|c|c|c|c|c|c|}
\hline & \multicolumn{3}{|c|}{$\begin{array}{l}\text { Crying for three or more } \\
\text { hours per 24-hour day }\end{array}$} & \multicolumn{3}{|c|}{ Crying a lot } & \multicolumn{3}{|c|}{ Difficult to comfort } \\
\hline & $\%$ & $O R$ & $95 \% C I$ & $\%$ & $O R$ & $95 \% C I$ & $\%$ & $O R$ & $95 \% C I$ \\
\hline Sex & $\mathrm{p}<0.05$ & & & $\mathrm{p}<0.01$ & & & & & \\
\hline Female & 5.9 & 1 & & 11.3 & 1 & & 10.3 & 1 & \\
\hline Male & 9.1 & 1.63 & $(1.14,2.34)$ & 16.4 & 1.59 & $(1.21,2.09)$ & 10.3 & 1.02 & $(0.75,1.39)$ \\
\hline Parity & & & & $\mathrm{p}<0.05$ & & & $\mathrm{p}<0.05$ & & \\
\hline Second and later born children & 6.8 & 1 & & 12.2 & 1 & & 8.9 & 1 & \\
\hline First born children & 8.4 & 1.25 & $(0.87,1.79)$ & 15.7 & $\underline{1.34}$ & $(1.02,1.77)$ & 11.6 & 1.30 & $(0.95,1.78)$ \\
\hline Ethnic origin & & & & $\mathrm{p}<0.05$ & & & $\mathrm{p}<0.05$ & & \\
\hline Dutch & 8.9 & 1 & & 15.1 & 1 & & 11.3 & 1 & \\
\hline Surinamese & 4.5 & $\underline{0.42}$ & $(0.22,0.82)$ & 6.9 & $\underline{0.38}$ & $(0.22,0.66)$ & 4.5 & $\underline{0.37}$ & $(0.19,0.71)$ \\
\hline Turkish & 10.0 & $\overline{1.12}$ & $(0.54,2.35)$ & 17.0 & $\overline{1.17}$ & $(0.65,2.11)$ & 7.0 & $\overline{0.59}$ & $(0.26,1.35)$ \\
\hline Moroccan & 6.3 & 0.67 & $(0.35,1.30)$ & 15.8 & 1.07 & $(0.67,1.69)$ & 11.6 & 1.02 & $(0.61,1.72)$ \\
\hline Other & 6.0 & 0.64 & $(0.38,1.09)$ & 14.0 & 0.91 & $(0.62,1.32)$ & 12.0 & 1.07 & $(0.72,1.60)$ \\
\hline \multicolumn{10}{|l|}{ Education of the mother } \\
\hline High & 7.5 & 1 & & 13.9 & 1 & & 10.2 & 1 & \\
\hline Poor & 7.7 & 1.03 & $(0.69,1.53)$ & 14.1 & 1.02 & $(0.75,1.39)$ & 10.4 & 1.18 & $(0.84,1.67)$ \\
\hline \multicolumn{10}{|l|}{ Type of feeding } \\
\hline Breast & 5.8 & 1 & & 12.0 & 1 & & 10.5 & 1 & \\
\hline Formula & 8.8 & 1.69 & $(1.11,2.59)$ & 14.9 & 1.39 & $(1.01,1.92)$ & 11.1 & 1.09 & $(0.77,1.54)$ \\
\hline Mixed & 8.3 & $\overline{1.69}$ & $(1.01,2.84)$ & 15.4 & $\overline{1.50}$ & $(1.02,2.21)$ & 8.0 & 0.82 & $(0.51,1.32)$ \\
\hline
\end{tabular}

Significant odds ratios are underlined. Odds ratio adjusted for all other sociodemographic factors. 
Table 3 Soothing techniques of mothers in response to infant crying (percentages)

\begin{tabular}{|c|c|c|c|c|}
\hline Soothing technique & $\begin{array}{l}\text { Total } \\
(n=1142)\end{array}$ & $\begin{array}{l}\text { Crying for } \geqslant 3 \\
\text { or more hours per } \\
24 \text { hour day } \\
(n=81)\end{array}$ & $\begin{array}{l}\text { Crying a lot } \\
(n=154)\end{array}$ & $\begin{array}{l}\text { Inconsolable } \\
\text { crying }(n=130)\end{array}$ \\
\hline Taking in bed & 60 & 85 & 84 & 75 \\
\hline Holding and carrying & 95 & 100 & 99 & 98 \\
\hline Buggy ride & 14 & 28 & 25 & 21 \\
\hline Car ride & 3 & 8 & 7 & 5 \\
\hline Music & 57 & 81 & 75 & 69 \\
\hline Rocking & 58 & 80 & 78 & 74 \\
\hline Pacifier & 84 & 90 & 90 & 90 \\
\hline Bathe & 22 & 38 & 33 & 35 \\
\hline Massage & 43 & 51 & 50 & 50 \\
\hline Herbal tea & 57 & 81 & 75 & 70 \\
\hline Crying it out & 45 & 68 & 65 & 53 \\
\hline Night bottle & 7 & 15 & 13 & 12 \\
\hline Swaddling & 14 & 22 & 21 & 19 \\
\hline Prone sleeping position & 28 & 37 & 41 & 33 \\
\hline Stopping breast feeding & 7 & 10 & 10 & 9 \\
\hline Admonishing & 24 & 39 & 38 & 35 \\
\hline Smothering & 2 & 5 & 4 & 2 \\
\hline Shaking & 5 & 6 & 10 & 12 \\
\hline Slapping & 3 & 8 & 8 & 7 \\
\hline Hypnotics and sedatives & 1 & 1 & 1 & 0 \\
\hline Painkillers & 3 & 7 & 5 & 4 \\
\hline Laxatives & 3 & 4 & 3 & 5 \\
\hline
\end{tabular}

and crying behaviours on the prevalence of various soothing techniques. A regression was carried out for each individual soothing technique. The results of these analyses are expressed as adjusted odds ratios. The level of significance used was $\mathrm{p}<0.05$.

\section{Results}

RESPONSE RATES

A questionnaire on sociodemographic characteristics and crying behaviours was filled out for 1826 infants (84\%). No information is available for the remaining infants. For 1142 $(63 \%)$ of the 1826 infants, a questionnaire about soothing techniques was returned as well. The mothers who did not return the questionnaire were more frequently of nonDutch origin $(\mathrm{p}<0.001)$ and more had a lower level of education $(p<0.001)$ and a first born child $(\mathrm{p}<0.001)$. No differences in response rate were found for crying behaviour and other sociodemographic characteristics.
CRYING BEHAVIOUR

Table 1 presents the study sample according to sociodemographic characteristics and reported crying behaviour. Overall prevalences of "crying for three or more hours/24 hour day", "crying a lot", and "difficult to comfort" were $7.6 \%, 14.0 \%$, and $10.3 \%$, respectively (table 1). Problematic infant crying, according to at least one criterion, was reported by $20.3 \%$ of the mothers. Of these crying infants, only $14 \%$ met all three inclusion criteria. Sex, parity, ethnic origin, and type of feeding were all related to crying behaviour (table 2). Perceived crying for three or more hours a day occurred less frequently in girls compared with boys, Surinamese infants compared with Dutch infants, and breast fed infants compared with formula or mixed fed infants. The same held true for infants whose mothers stated that their infant cries a lot. Furthermore, primiparous mothers stated more frequently that their infant cries a lot compared with multiparous mothers. Surinamese mothers reported less frequently that their infant was difficult to comfort compared with Dutch mothers.

SOOTHING TECHNIQUES

Mothers used various soothing techniques to calm their babies. In addition to harmless methods, mothers also used techniques that could affect the infant's health negatively (table 3). Most soothing methods were related to sociodemographic variables (table 4). Reported shaking, slapping, and putting the baby to sleep in a prone position were more common among non-Dutch mothers than among Dutch mothers. This held true especially for Turkish mothers $(\mathrm{OR}=6.36$ for shaking; $\mathrm{OR}=6.37$ for slapping; and $\mathrm{OR}=3.93$ for prone sleeping position). Poorly educated mothers also reported slapping their baby more often than highly educated mothers $(\mathrm{OR}=4.08)$. Moroccan mothers rocked (0.56), held, and carried their baby less frequently than Dutch mothers in response to infant crying $(\mathrm{OR}=0.24)$.

Table 4 Multivariate odds ratios of soothing techniques by sociodemographic factors and crying behaviour

\begin{tabular}{|c|c|c|c|c|c|c|c|c|}
\hline Soothing technique & $\begin{array}{l}\text { Boy } \\
\text { v girl }\end{array}$ & $\begin{array}{l}\text { First } v \\
\text { later born }\end{array}$ & $\begin{array}{l}\text { Surinam } \\
v \text { Dutch }\end{array}$ & $\begin{array}{l}\text { Turkey } \\
\text { v Dutch }\end{array}$ & $\begin{array}{l}\text { Morocco } \\
\text { v Dutch }\end{array}$ & $\begin{array}{l}\text { Other } \\
\text { country } \\
\text { v Dutch }\end{array}$ & $\begin{array}{l}\text { Poorv high } \\
\text { education }\end{array}$ & $\begin{array}{l}\text { Crying infant } \\
\text { v not crying } \\
\text { infant }\end{array}$ \\
\hline Taking in bed & - & - & - & - & - & - & - & 2.49 \\
\hline Holding and carrying & - & $(1.68)$ & $(0.48)$ & - & 0.24 & $(0.47)$ & $(0.54)$ & 2.66 \\
\hline Buggy ride & - & - & 0.32 & - & - & - & - & 1.97 \\
\hline Car ride & - & - & - & - & - & - & - & 2.42 \\
\hline Music & - & 1.78 & - & - & 0.58 & - & 1.45 & 1.99 \\
\hline Rocking & $(1.24)$ & 1.34 & - & 3.94 & 0.56 & 0.64 & 0.56 & 2.30 \\
\hline Pacifier & 1.42 & 1.39 & - & - & - & 0.49 & $(1.41)$ & $(1.51)$ \\
\hline Bathe & - & - & - & - & - & - & - & 1.97 \\
\hline Massage & - & 1.36 & 0.55 & $(2.06)$ & - & - & - & $(1.34)$ \\
\hline Herbal tea & 1.31 & 1.45 & $(0.67)$ & 3.67 & $(0.63)$ & 0.61 & - & 2.05 \\
\hline Crying it out & - & - & - & $(1.92)$ & - & - & 1.61 & 1.81 \\
\hline Night bottle & - & - & 2.74 & 5.40 & 7.37 & 2.96 & 2.71 & 2.20 \\
\hline Swaddling & - & - & $(0.46)$ & $(2.56)$ & 3.10 & - & 0.24 & $(1.47)$ \\
\hline Prone sleeping position & - & 0.75 & 2.61 & 3.93 & 1.90 & 1.55 & - & 1.46 \\
\hline Stopping breast feeding & - & - & - & - & - & - & 1.84 & - \\
\hline Amonishing & $(1.30)$ & 1.71 & - & 4.45 & - & - & - & 1.87 \\
\hline Shaking & - & - & - & 6.36 & $(2.52)$ & 4.32 & - & 2.24 \\
\hline Slapping & - & - & $(2.71)$ & 6.37 & $(3.26)$ & 5.92 & 4.08 & 3.02 \\
\hline Laxatives & - & - & - & - & - & - & $(1.93)$ & - \\
\hline
\end{tabular}

Only odds ratios with $p<0.05$ or $p<0.10$ are presented; $p<0.10$ for odds ratios in parentheses. No multivariate odds ratios were calculated for "smothering", "hypnotics and sedatives", and "painkillers", because of empty cells in logistic regression model. *According to at least one of the three definitions mentioned. 


\section{Discussion}

This study shows that the overall prevalence of reported problematic crying in babies aged 2-3 months differs according to the definition used: $7.6 \%$ for crying for three or more hours $/ 24$ hour day, $14.0 \%$ for crying a lot, and $10.3 \%$ for inconsolable crying. Problematic infant crying according to one or more criteria was reported by $20.3 \%$ of the mothers. Many mothers used soothing techniques that could affect the infant's health negatively. Mothers' reports of infant crying and soothing varied sociodemographically. Excessive crying was less common among girls, breast fed infants, and Surinamese infants. Soothing methods that can be injurious to infants' health, such as slapping, shaking, and prone sleeping position, were more prevalent among non-Dutch mothers (especially Turkish) than among Dutch mothers.

Theoretically, a selective non-response among non-Dutch families might bias overall prevalences of crying babies. A selective high non-response among non-Dutch families is a common problem in surveys carried out in the multicultural cities of the Netherlands. However, in this study the non-response rate for the verbal questionnaire was very low, probably as a result of the reputation of the child health clinics, as well as the experience of the nurses and physicians at these clinics in contacting and interviewing respondents. Apart from this, a previous survey in these six child health centres showed that attendance rates vary little according to ethnic group. ${ }^{24}$

A selective non-response was found for the mail questionnaire on soothing techniques. As a result, overall prevalences might be biased. Furthermore, the results might be biased by differences in socially desirable responses. For instance, it is possible that Dutch mothers slap and shake their children more often than they reported. It is also possible that "slapping" and "shaking" might have different meanings in different ethnic groups.

Of all problematic crying infants, only $14 \%$ met all three criteria. We find it remarkable that only $39 \%$ of the infants who cry a lot are also reported to cry for three or more hours/24 hour day. Conversely, of the infants who cry for three or more hours $/ 24$ hour day, $78 \%$ were also reported to cry a lot. Apparently, some parents cannot tolerate the least amount of crying, while others do not experience long crying periods as troublesome. Therefore, intervention efforts should be guided by parents' perceptions of infant crying, irrespective of the actual amount of crying.

EXCESSIVE CRYING BY SOCIODEMOGRAPHIC

CHARACTERISTICS

Different definitions of a crying infant lead to different conclusions about the sociodemographic factors associated with reported crying. For example, there was no association between parity and crying for three or more hours/day. This is in agreement with other studies. $^{24}{ }^{25-27}$ However, crying a lot was reported to be more common among infants of primiparous mothers. Perhaps primiparous

\section{Key messages}

- Problematic infant crying was reported by $20.3 \%$ of mothers

- Many mothers used soothing techniques that could affect their infant's health negatively

- Undesirable soothing techniques were more prevalent among immigrant mothers

- Much harm might be prevented by counselling parents (especially immigrants) on how and how not to respond to infant crying

mothers experience the same amount of crying as more troublesome. Furthermore, primiparous mothers were more likely to seek referral for infant crying than mothers of later born infants. ${ }^{24}$

Reported excessive crying appeared to be more common in boys than in girls. Other studies reported no sex differences in the prevalence of excessive crying ${ }^{12829}$ or mean amount of crying. ${ }^{243031}$ However, most of these studies were based on small selective groups and data were sampled for purposes other than establishing sex differences in the amount of infant crying. One previous study found modestly increased crying in boys. ${ }^{32}$

Reported excessive crying was more frequent among Dutch infants than among Surinamese infants. We found only two other studies in Western multicultural societies dealing with ethnic differences in excessive infant crying. In an Australian study, excessive crying was reported more commonly in infants with parents born in Lebanon, Asia, and South and Central America. ${ }^{33} \mathrm{~A}$ study in the USA among low birthweight infants showed that excessive crying was much less frequent among black infants than among white infants. ${ }^{27}$ This might reflect ethnic differences in genetic predisposition, care giving practice, or soothing techniques. Given that these studies were based on maternal reports, ethnic differences in maternal perceptions of crying might also be an explanation.

Poorly educated mothers did not differ from highly educated mothers in their reports of excessive crying. This is in accordance with other studies..$^{28} 30$ In some studies, however, more infant crying was reported in higher socioeconomic groups $^{1029}$ or lower socioeconomic groups. ${ }^{26}$ These inconsistent findings can be explained partly by different indicators of socioeconomic status in different studies. Socioeconomic health differences in children vary strongly depending on the indicator of socioeconomic status. ${ }^{34}$

Breast fed infants cried less than formula or mixed fed babies. This may not be related to the content of feeding. For instance, excessive infant crying is a common reason for mothers to switch from breastfeeding to bottle feeding. Furthermore, bottle fed infants might cry excessively because the child health clinic prescribes an insufficient amount of formula 
feeding, ${ }^{35}$ whereas breast fed babies can control the amount they feed. A Dutch study has shown that breast fed infants feed more frequently and/or were more frequently fed on demand than those who were bottle fed. ${ }^{36}$ These two factors are associated with a decrease in infant crying. ${ }^{16}{ }^{37}$

SOOTHING TECHNIQUES

There is evidence that picking up and carrying, ${ }^{31} 3839$ rocking, ${ }^{40}$ auditory stimulation, ${ }^{41}{ }^{42}$ pacifiers, ${ }^{43}{ }^{44}$ and herbal tea ${ }^{45}$ are effective soothers. Whether these techniques reduce crying in the long run is not known. In addition, some soothers that have been shown to be highly effective in experimental research are not perceived as such by mothers. ${ }^{46}$

Some soothing methods must be strongly discouraged, because of their possible injurious effect on the child's health. The most dangerous techniques a parent can use are to smother, slap, or shake the baby to make it quiet. Nonetheless, these techniques were reported by $2 \%$, $3 \%$, and $5 \%$ of mothers, respectively. Among mothers of infants with problematic crying, these prevalences were two to three times higher. Excessive crying has been identified as a major cause of child abuse, ${ }^{47}$ which could be fatal in infants, because of their inability to escape harm and their physical vulnerability to serious trauma. ${ }^{48}$

Some studies suggest that ignoring a crying baby is effective in reducing the amount of crying. ${ }^{49}{ }^{50}$ Ignoring the infant's crying or leaving the infant alone when crying is a common response in Western societies. ${ }^{31} 51$ In our study, $45 \%$ of mothers let the baby cry on at least one occasion. It is unclear how this behaviour affects the parent-child relationship. In a study dealing with the circumstances of 222 sudden unexpected deaths, five infants died in the night when the parents had let it continue to cry for the first time. ${ }^{52}$

Crying in breast fed infants can be a symptom of allergy to cow's milk products consumed by the mother. ${ }^{53}$ It is better to eliminate these products from the mother's diet than to stop breastfeeding, ${ }^{54}$ which protects children from various diseases, especially infectious ones. $^{55}$ Moreover, infants who had been switched to formula feeding were no more quiet than infants who were exclusively breast fed. ${ }^{36}$

Swaddling (wrapping the baby in a blanket) appears to be soothing, ${ }^{56}$ but some forms of wrapping increase the risk of a congenital dislocation of the hip. ${ }^{57}$

Laying infants prone to sleep increases the risk of cot death, ${ }^{58}$ so it is not acceptable to place the baby in this position to stop it crying. In a series of 108 sudden unexpected deaths, six infants died during their sleep when they were put to sleep in a prone position for the first time. ${ }^{59}$ In a series of 222 other sudden unexpected deaths this was the case with eight infants. $^{52}$

Some mothers assume that infant crying is caused by constipation, but the lack of evidence means laxatives should be discouraged. Hypnotics and sedatives should not be used because of a possible relation to brain damage and cot death. ${ }^{60}$

SOOTHING TECHNIQUES BY SOCIODEMOGRAPHIC CHARACTERISTICS

Primiparous mothers were shown to admonish their baby more often in response to crying than multiparous mothers. Similarly, Boukydis and Burgess ${ }^{61}$ noted that first time parents respond to crying with greater arousal and more irritation than multiparous parents.

It is notable that Turkish and Moroccan mothers relatively frequently admonished, slapped, and shook their infant in response to crying. Perhaps punishment is a common child rearing practice with young children in those cultural groups. In a study of bed wetting in Amsterdam, relatively more Dutch parents praised their toddlers for a dry night, while relatively more immigrant parents punished their toddlers for a wet night. ${ }^{62}$

Many Turkish mothers placed their baby to sleep in the prone position in response to crying. This is probably one reason why, in the Netherlands, Turkish infants are almost twice as likely to suffer cot death than Dutch infants. ${ }^{63}$ It is possible that the more frequent use of slapping and shaking among Turkish mothers also contributes to this higher risk. ${ }^{64}$

\section{IMPLICATIONS}

Much harm may be prevented by counselling parents (especially immigrants) on how and how not to respond to infant crying. It is important to identify inappropriate parental responses and to suggest alternatives. Furthermore, it is practical to ask parents whether they detect differences in the effectiveness of their soothing methods, because effective soothing strategies differ for each child.$^{65}$ Health education should start before the child's birth, because some soothing techniques can be fatal, even when practised for the first time, such as the prone sleeping position, allowing the baby to continue to cry, smothering, and shaking.

1 Canivet C, Hagander B, Jakobsson I, Lanke J. Infantile colic: ess common than previously estimated? Acta Paediatr 1996;85:454-8

2 Alvarez M, St James-Roberts I. Infant fussing and crying patterns in the first year in an urban community in Denmark. Acta Paediatr 1996;85:463-6.

3 Lehtonen L, Korvenranta H. Infantile colic: seasonal incidence and crying profiles. Arch Pediatr Adolesc Med 1995;149:533-6.

4 St James-Roberts I, Halil T. Infant crying patterns in the first year: normal community and clinical findings. $f$ Child Psychol Psychiat 1991;32:951-68.

5 Michelsson K, Rinne A, Paajanen S. Crying, feeding and sleeping patterns in 1 to 12 -month-old infants. Child Care Health Dev 1990;16:99-111.

6 Lothe L, Ivarsson SA, Ekman R, Lindberg T. Motilin and infantile colic: a prospective study. Acta Paediatr Scand 1990;79:410-6.

7 Thomas DW, McGilligan K, Eisenberg LD, Lieberman HM, Rissman EM. Infantile colic and type of milk feeding. Am $\mathcal{F}$ Dis Child 1987;141:451-3.

8 Forsyth BWC, McCarthy PL, Leventhal JM. Problems of early infancy, formula changes and mothers' beliefs about their infants. F Pediatr 1985;106:1012-7.

9 Rubin SP, Prendergast M. Infantile colic: incidence and treatment in a Norfolk community. Child Care Health Dev 1984;10:219-26.

10 Hide DW, Guyer BM. Prevalence of infant colic. Arch Dis Child 1982;57:559-60.

11 Gray P. Crying baby: how to cope. London: Wisebuy, 1987.

12 Geertsma MA, Hyams IS. Colic: a pain syndrome of infancy? Pediatr Clin North Am 1989;36:905-19.

13 Lee K. The crying pattern of Korean infants and related factors. Dev Med Child Neurol 1994;36:601-7. 
14 Barr RG, Konner M, Bakeman R, Adamson L. Crying in Kung San infants: a test of the cultural specificity hypoth-

15 Hunziker UA, Barr RG. Increased carrying reduces infant crying: a randomized controlled trial. Paediatrics 1986;77: 641-8.

16 Barr RG, Elias MF. Nursing interval and maternal responsivity: effect on early infant crying. Paediatrics $1988 ; 81: 529$ 36.

17 Van den Boom DC. The influence of temperament and mothering on attachment and exploration: an experimental manipulation of sensitive responsiveness among lower-class
mothers with irritable infants. Child Dev 1994;65:1457-77.

18 Van den Boom DC. Do first-year intervention effects Dutch irritable infants. Child Dev 1995;66:1798-1816.

19 Rinne A, Saenz AH, Michelsson K. Amount and perception of baby crying in Finland and Colombia. Early Child Dev
Care 1990;65:139-44.

20 St James-Roberts I, Bowyer J, Varghese S, Sawdon J. Infant crying patterns in Manali and London. Child Care Health crying patterns in Ma

21 Barr RG, Kramer MS, Boisjoly C, McVey-White L, Pless IB. Parental diary of infant cry and fuss behaviour. Arch Dis Child 1988;63:380-7.

22 St James-Roberts I, Bowyer J, Hurry J. Delineating "problem" infant crying; findings in community and referred infants, using tape recordings, diaries and questionnaires. Paper presented at the 1991 Biennial Meeting of the Society for Research in Child Development, April 18-20, 1991, Seattle, WA

23 Norusis MJ. SPSS/PC base system user's guide and advanced statistics, version 5.0. Chicago: SPSS, 1992.

24 Van der Wal MF, Rijcken B. Astmatische klachten bij autochtone en allochtone kinderen van 2-11 jaar. Tijdschrift Sociale Gezondheidszorg 1995;73:42-50.

25 Beebe SA, Casey R, Pinto-Martin J. Association of reported infant crying and maternal parenting stress. Clin Pediatr infant crying and

26 Said G, Patois E, Lellouch J. Infantile colic and parental smoking. BMF 1984;289:660.

27 Meyer JE, Thaler MM. Colic in low birth weight infants. $A m$ 7 Dis Child 1971;122:25-7.

28 Ståhlberg MR. Infantile colic: occurrence and risk factors. Eur f Pediatr 1984;143:108-11.

29 Paradise JL. Maternal and other factors in the etiology of infantile colic. $¥ A M A$ 1966;197:123-31.

30 Baildam EM, Hillier VF, Ward BS, Bannister RP, Bamford $\mathrm{FN}$, Moore WMO. Duration and pattern of crying in the first year of life. Dev Med Child Neurol 1995;37:345-53.

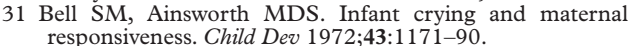

32 St James-Roberts I, Plewis I. Individual differences, daily fluctuations and developmental changes in amounts of infant waking, fussing, crying, feeding and sleeping. Child Dev 1996;67:2527-40.

33 Prior M, Garino E, Sanson A, Oberklaid F. Ethnic influences on "difficult" temperament and behavioural problems in infants. Aust f Psychol 1987;39:163-71.

34 Van der Lucht F. Sociale ongelijkheid en gezondheid bij kinderen:een empirisch onderzoek naar causatie - en selectieprocessen ren:een empirisch onderzoek naar causatie - en selectieprocessen
met betrekking tot gezondheid bij kinderen van 10-11 jaar. met betrekking tot gezondheid bij kinderen van

35 Croughs RWM. Enkele veel huilende jonge zuigelingen. Tijdschrift feugdgezondheidszorg 1986;18:83-5

36 Joossen JJJ, Jenniskens DMAL. Voedingsfrequentie en groei van zuigelingen van 1 tot 4 maanden. Tijdschrift Sociale Gezondheidszorg 1986;64:833-4.

37 Barr RG, Kramer MS, Pless IB, Boisjoly C, Leduc D. Feeding and temperament as determinants of early infant crying/fussing behaviour. Paediatrics 1989;84:514-21.

38 Gekoski MJ, Rovee-Collier CK, Carulli-Rabinowitz V. A longitudinal analysis of inhibition of infant distress: the origins of social expectations? Infant Behav Dev 1983;6:33951 .

39 Korner AF, Thoman EB. The relative efficacy of contact and vestibular-proprioceptive stimulation in soothing and vestibular-proprioceptive stimulat

40 Pederson DR. The soothing effect of rocking as determined by the direction and frequency of movement. Can $\mathcal{F}$ Behav Sci $1975 ; 7: 237-43$.
41 Brackbill Y, Adams G, Crowell DH, Gray ML. Arousal level in neonates and preschool children under continuous auditory stimulation. F Exp Child Psychol 1966;4:178-88.

42 Birns B, Blank M, Bridger WH, Escalona SK. Behavioral inhibition in neonates produced by auditory stimuli. Child Dev 1965;36:639-45.

43 Anderson GC. Pacifiers: the positive side. Matern Child Nurs f 1986;11:122-4.

44 Levine MI, Bell AI. The treatment of "colic" in infancy by use of the pacifier. F Pediatr 1950;37:750-5.

45 Weizman Z, Alkrinawi S, Goldfarb D, Bitran C. Efficacy of herbal tea preparation in infantile colic. F Pediatr 1993;122:650-2.

46 Ames EW, Gavel S, Khazaie S, Farrell T. Mothers' reports of infant crying and soothing. Paper presented at international conference on infant studies, April 1984, New York.

47 Frodi A. When empathy fails: aversive infant crying and child abuse. In: Lester BM, Boukydis CFZ, eds. Infant crying: theoretical and research perspectives. New York/London: Plenum Press, 1985:263-77.

48 Showers J, Apolo J, Thomas J, Beavers S. Fatal child abuse: a two-decade review. Pediatr Emerg Care 1985;1:66-70.

49 McKenzie S. Troublesome crying in infants: effect of advice to reduce stimulation. Arch Dis Child 1991;66:1416-20.

50 Rickert VI, Johnson CM. Reducing nocturnal awakening and crying episodes in infants and young children: a comparison between scheduled awakenings and systematic parison between saediatrics 1988;81:203-12.

51 Hubbard FOA, van IJzendoorn MH. Maternal unresponsiveness and infant crying. A critical replication of the Bell and Ainsworth study. In: Tavecchio LWC, van IJzendoorn $\mathrm{MH}$, eds. Attachment in social networks: contributions to the Bowlby-Ainsworth attachment theory. Amsterdam: Elsevier, 1987:339-75.

52 De Jonge GA, Kostense PJ, Pieterson I. Prävention des plötzlichen Kindstodes. In: Trowitzsch E, Schlütter B, Andler W, eds. Prävention des SID. Berlin: Acron Verlag, 1993:90104 .

53 Jakobsson I, Lindberg T. Cow's milk proteins cause infantile colic in breast-fed infants: a double-blind crossover study. Paediatrics 1983;71:268-71.

54 Hill DJ, Hudson IL, Sheffield LJ, Shelton MJ, Menahem S, Hosking CS. A low allergen diet is a significant intervention in infantile colic: results of a community-based study. 7 in infantile colic: results of a comm Immunol 1995;96:886-92.

55 Lawrence PB. Breast milk. Best source of nutrition for term and preterm infants. Pediatr Clin North Am 1994;41:92541 .

56 Lipton EL, Steinschneider A, Richmond JB. Swaddling, a child care practice: historical, cultural and experimental observations. Paediatrics 1965;35(suppl):521-67.

57 Kutlu A, Memik R, Mutlu M, Kutlu R, Arslan A. Congenital dislocation of the hip and its relation to swaddling used in Turkey. F Pediatr Orthop 1992;12:598-602.

58 Fleming PJ, Blair PS, Bacon C, et al. Environment of infants during sleep and risk of the sudden infant death syndrome: results of 1993-5 case-control study for confidential inquiry into stillbirths and deaths in infancy. $B M \mathcal{F}$ 1996;313:191-5.

59 Engelberts AC. Cot death in the Netherlands: an epidemiological study. Amsterdam: Free University, 1991. Dissertation.

60 Kahn A, Blum D. Phenothiazines and sudden infant death syndrome. Paediatrics $1982 ; 70: 75-8$.

61 Boukydis CFZ, Burgess RL. Adult physiological response to infant cries: effects of temperament of infant, parental status and gender. Child Dev 1982;53:1291-8.

62 Van der Wal MF, Pauw-Plomp H, Schulpen TWJ. Bedplassen bij Nederlandse, Surinaamse, Marokkaanse en Turkse kinderen van 3-4, 5-6 en 11-12 jaar. Ned Tijdschr Geneeskd 1996;140:2410-14.

63 De Jonge GA, Hoogenboezem J. Wiegendood in Nederland in de periode 1980-1993. Ned Tijdschr Geneeskd 1994;138: 2133-7.

64 Emery JL. Child abuse, sudden infant death syndrome, and unexpected infant death. Am F Dis Child 1993;147:1097100.

65 Birns B, Blank M, Bridger WH. The effectiveness of various soothing techniques on human neonates. Psychosom Med 1966;28:316-22. 